\title{
Impact of Performance Appraisal on Organizational Citizenship Behaviour and Intention to Stay through Affective Commitment: A Literature Review
}

\author{
Ravikumar R. K., Dr. R. P. Raya \\ Ph.D. Research Scholar \\ Department of Management Studies School of Management Pondicherry University Pondicherry-605014 \\ Professor, \\ Department of Management Studies School of Management \\ Pondicherry University Pondicherry-605014
}

\begin{abstract}
The purpose of this paper is to develop theoretical framework linking performance appraisal, affective commitment, intention to stay, and organizational citizenship behaviour. The social exchange and procedural justice theories applied to link performance appraisal with affective commitment, intention to stay, and organizational citizenship behaviour. Propositions were framed based on the in-depth literature review and tested the propositions based on the previous similar findings. This study will provide platform to conduct empirical study to examine the impact of performance appraisal on affective commitment, intention to stay, and organizational citizenship behaviour.
\end{abstract}

\section{Introduction}

Social exchange relationship between organization and employees is reciprocal and obligatory in nature. Employee engage proactively to their job and put forth extra effort to achieve organizational goals when they perceive organizational practices, policies and approaches are favourable. Performance appraisal is one of the important human resource management practices which employees eagerly wait for it throughout the year. Performance appraisal system has been designed to evaluate the performance of the employees based on the predetermined parameters, which are required to capture all the aspect of employee performance. The formal performance appraisal process includes establishing work objectives and setting performance goals, performance review and feedback meetings, and conducting self-appraisals. The performance appraisal results decide employee's future promotion, monetary benefit and training and development. Performance appraisal system can be a source of employee motivation when employees perceive their performance appraisals as precise and impartial (Thurston $\mathrm{Jr} \& \mathrm{McNall,} 2010$ ). The performance appraisal process is increasingly seen as a key link between employee behaviour and an organization's strategic objectives. Unfortunately, performance reviews often fail to change how people work, and dissatisfaction with the appraisal process has been associated with general job dissatisfaction, lower organizational commitment, and increased intentions to quit (Dusterhoff, Cunningham, \& MacGregor, 2014). The processes inherent in these systems and the performance appraisal outcomes themselves can have an important influence on employees' reactions toward their work, their supervisors, and their organization as a whole. However, the performance appraisal is partly subjective because employees have been evaluated by their supervisors, their feedback on employee performance may be biased. Another issues in performance appraisal is the performance measurement tools, often these tools are criticized for not being able the capture accurately the performance of the employees. The appraisal process can also lead to frustration and dissatisfaction when employees perceive that the performance appraisal system is politically motivated and biased (Skarlicki and Folger, 1997).

Performance appraisal has been done for all the employees working in the organizations, the satisfaction level of the employees may be different at different level. Employees working in senior 
management, middle management, and junior level may experience performance appraisal differently, since they have different roles and responsibilities. Integrating social exchange theory with procedural justice theory, this study tested the direct effect of perception of performance appraisal on intention to stay and organizational citizenship behaviour and indirect effect thorough the affective commitment. Further, this study examines the moderating role of job position in the relationship performance appraisal, affective commitment, intention to stay, and organizational performance.

\section{Literature Review}

Studies have been conducted to examine the impact of performance appraisal on intention to stay, however, few studies cover the justice perception of the performance appraisal. For instance, Brown, Hyatt, and Benson (2010) examine the role of low quality performance appraisals on intention to quit. Majority of the researchers have studied the impact to HRM practices on intention to stay, which include performance appraisal as one of the HRM practices, however, this performance construct did not include the various dimensions and justice perception of performance appraisal. For example, Min, Zhu, and Bambacas (2019) explore the effect of high-performance work systems on intention to stay in Chinese indigenous firms. Jyoti and Rani (2019) examined the role high performance work system and intention to leave.

There are few studies which have conducted to examine the influence of performance appraisal on organizational citizenship behaviour. For example, Lu, Yue, Han, and Chen (2018) examined the effect of performance appraisal purposes (developmental and evaluative) on miners' organizational citizenship behaviour. Isenhour, Stone, Lien, Zheng, Zhang, and Li (2012) examined how performance appraisal process (observation, planning and feedback) is associated with organizational citizenship behaviour. Tang and Tang (2012) examined the influence of high-performance human resource (HR) practices on serviceoriented organizational citizenship behaviour. Snape and Redman (2010) examine the relationship between HRM practices and organizational citizenship behavior among the employees in North-East England.

Few researchers have linked performance appraisal with it antecedents. For instance, Dusterhoff, Cunningham, and MacGregor (2014) studied effects of performance rating, leader-member exchange, perceived utility, and organizational justice on performance appraisal satisfaction. Palaiologos, Papazekos, and Panayotopoulou (2011) examined the effect of procedural, distributive and interactional justice on the perception of the performance appraisal.

The studies have been conducted to examine the impact of performance appraisal on intention to stay and organizational citizenship behavior through various mediating variables. For instance, Thurston Jr and McNall (2010) examined the role of justice perception of performance appraisal on organizational citizenship behavior through the satisfaction with appraisal. Min, Zhu, and Bambacas (2019) explore the mediating effect of trust on the relationship between high-performance work systems and intention to stay in Chinese indigenous firms. Lu, Yue, Han, and Chen (2018) examined the effect of performance appraisal purposes (developmental and evaluative) on miners' organizational citizenship behavior (OCB) via organizational identification. Jyoti and Rani (2019) examined the role of burnout as a mediator between high performance work system and intention to leave. Tang and Tang (2012) examined the influence of highperformance human resource (HR) practices on service-oriented organizational citizenship behaviour (OCB) through two climates - justice climate and service climate in hotel in Taiwan. Snape and Redman (2010) examined the relationship between HRM practices, conceptualized at the workplace level, and individual employee attitudes and behaviour through an effect on perceived job influence/discretion.

There are few studies which examined the mediating role of organizational commitment in the relationship between performance appraisal and intention stay and organizational citizenship behaviour. Most importantly, Heslin and VandeWalle (2011) studied relationship between the procedural justice perceptions of performance appraisal and employees' organizational citizenship behaviour, and mediating role by organizational commitment. Phuong (2018) studied the impact of participative performance appraisal, performance appraisal training, trust in rater and the use of forced distribution ranking system on intention to quit and job performance through the perceived procedural justice and distributive justice in performance appraisal in Vietnamese companies. Brown, Hyatt, and Benson (2010) examine the role of low quality performance appraisals (PA) on intention to quit through the job satisfaction, organizational commitment. However, these studies did not examine the influence of multi-dimensional justice perception of the performance appraisal, which is comprehensive construct to examine the justice perception of the performance appraisal. 
Theoretical Framework and Proposition Development

\section{Performance Appraisal and Organizational Citizenship Behaviour}

The performance appraisal practices often include formal review and feedback sessions, and may include procedures for establishing work objectives, conducting self-appraisals, and setting performance goals. Performance appraisal process and outcomes can influence the employees' organizational citizenship behaviour (Thurston Jr \& McNall, 2010). Organizational citizenship behaviour (OCB) denotes to employee behaviour that is extra-role, which strengthen organizational effectiveness, and which is not the part of organization's formal behaviour (Organ, 1988), such as voluntary and informal behaviours, like helping coworkers and the organization (Saks, 2006). Employees display organizational citizenship behaviour only if they believe that their organization fulfil the promise and done justice to them (Robinson \& Morrison,1995). Sense dissatisfaction and lack of justice perception create hindrance in displaying voluntary and informal behaviour in the organization. Hence, the justice perceptions of the performance appraisal likely to influence organizational citizenship behaviour (Thurston $\mathrm{Jr} \& \mathrm{McNall}, 2010$ ). Thus, the following proposition is framed.

P1: Performance appraisal will be positively related to organizational citizenship behaviour.

\section{Performance Appraisal and Intention to Stay}

Employees always look for benefit they receive in their organizations and lack of perceived befit influence them to leave the organizations (Chew \& Chan, 2008; Juhdi, Pa'wan, \& Hansaram, 2013), however, employees also intend to leave their organization if they find their job stressful and lack of recognition (AbuAlRub \& AL-ZARU, 2008). Similarly, the perceive fairness regarding the performance evaluation have influence on employees' intention to stay in their organization (Armstrong-Stassen, Freeman, Cameron, \& Rajacic, 2015). Importantly, the performance appraisal outcomes play important role for employees' salary increment and promotion, hence, employees give much importance to the performance appraisal system and process. The quality of the performance appraisal experience may vary among the employees and high quality experience results in higher intentions to stay (Brown, Hyatt, \& Benson, 2010). Thus, the following proposition has been proposed.

P2: Performance appraisal will be positively related to intention to stay.

\section{Performance Appraisal and Affective Commitment}

Affective commitment refers to psychological and emotional attachment to the organization (Meyer \& Allen, 1991). It develops over a period of time when employee feel positive about their organizations' policies and practices, and it gets stronger when employees continuously perceive the benefit of organizations' policies and practices. The performance appraisal practice is considered as essential factor for changing employees' attitude and behaviour such as affective commitment (Morrow, 2011). Studies of Kuvaas (2006) and Iqbal, Akbar, and Budhwar (2015) also indicated the positive relationship between performance appraisal and affective commitment. Thus, justice perception of the performance appraisal system likely to positively influence affective commitment. Hence, the following proposition has been framed.

P3: Performance appraisal will be positively related to affective commitment.

\section{Affective Commitment and Organizational Citizenship Behavior}

Affective commitment has been positively linked to organizational citizenship behavior (Liu, et al., 2018; Charbonneau, \& Wood, 2018). Employee who is strongly committed to their organization would work beyond formal role and responsibility and help co-workers and organization (Pradhan \& Pradhan, 2015). Employees with strong affective commitment shown a greater interest to involve in organizational citizenship behaviors (Wang, Weng, \& Jiang, 2018). Empirical studies also indicated the positive relationship between affective commitment and organizational citizenship behavior (Zayas-Ortiz, et al., 2015; Harwiki, 2016). The affective commitment is likely to influence positively to the organizational citizenship behavior. Thus, the following proposition has framed.

P4: Affect commitment will have positive affect on organizational citizenship behavior. 
Stronger affective commitment indicates the stronger emotional attached with their organization, emotionally attached employees consider organization's problem their own (Allen \& Meyer, 1990). Strongly committed employees are more likely to stay in their organizational compared to less committed employee (Allen \& Meyer, 1990). In the various studies affective commitment has been positively linked to employee intention to stay in the verity of organizations (Meyer et al., 2002; Jaros, 1997; Meyer et al., 2002). Thus, following proposition is formulated.

P5: Affective commitment is positively related to the intention to stay.

\section{Mediating role of Organizational Commitment}

According to the rule of mediation suggested by Baron and Kenny (1986), the independent variable, i.e., performance appraisal positively link to affective commitment, and affective commitment further positively link to dependent variables such as organizational citizenship behaviour and intention stay. Hence, affective commitment may be act as mediator in the relationship between performance appraisal and organizational citizenship behaviour, intention to stay. Thus, following propositions are framed.

P6: Affective commitment mediates the relationship performance appraisal and organizational citizenship behaviour.

P7: Affective commitment mediates the relationship performance appraisal and intention to stay.

\section{Moderating role of Job position}

This study examines the moderating role of job position/role in the relationship between performance appraisal and affective commitment, organizational citizenship behavior, and intention stay. Performance appraisal system covers all the employees in the organization. Performance appraisal evaluate the performance of all the employees in the organization whether they work at senior and middle management or junior level. Employees at these three levels likely to have different experience. Hence, job position is likely to moderate the influence of perception of performance appraisal on affective commitment, organizational citizenship behaviour, and intention to stay. Thus, following proposition is formulated.

P8: Job position will moderate the relationship between performance appraisal and outcome variables.

\section{Findings and Discussions}

The positive relationship between performance appraisal and organizational citizenship behaviour has been proposed, this proposition P1 is supported by the previous studies. For instance, Zheng, Zhang, and Li (2012) found positive relationship between performance appraisal process and organizational citizenship behaviour, whereas, Snape and Redman (2010) found positive relationship between HRM practices (training, appraisal, and career development) and organisational citizenship behaviour. Employees display organizational citizenship behaviour when they perceive performance appraisal process is fair. The proposition P2, positive relationship between performance appraisal and intention to stay is also supported. For example, Kuvaas (2006) positive relationship between Performance appraisal satisfaction and employee intention to stay. Employee are more likely to stay in the organization when they are satisfied with the performance appraisal. The proposition P3, positive relationship between performance appraisal and affective commitment is supported by the findings of previous studies. For instance, Ahuja, Padhy, and Srivastava (2018) found positive relationship between performance appraisal satisfaction and affective commitment. The satisfaction with performance appraisal attach employees emotionally with their organization. The propositions P4 and P5, positive impact of affective commitment on organizational citizenship behaviour and intention to stay respectively are also supported. Devece, Palacios-Marqués, and Alguacil (2016) and Zayas-Ortiz, Rosario, Marquez, and Colón Gruñeiro (2015) positive and stronger relationship between affective commitment and organizational citizenship behaviour. Similarly, Jang and Kandampully (2018) and Redditt, Gregory, and Ro (2019) found positive relationship between affective commitment and intention to stay. Findings show that the affectively committed employees stay in their organization. The proposition P6 that affective commitment mediates the relationship performance appraisal and organizational citizenship behaviour, and proposition P7 that affective commitment mediates the relationship performance appraisal and intention to stay are also supported. Zheng, Zhang, and Li (2012) 
found mediating role of affective commitment in the relationship between performance appraisal process and organizational citizenship behaviour, whereas Juhdi, Pa'wan, and Hansaram (2013) mediating role of organizational commitment in the relationship between performance appraisal and intention to stay. The findings indicate that performance appraisal positively influence intention to stay through the affective commitment. The Proposition P8 that job position moderates the relationship between performance appraisal and outcome variables is supported. Kuvaas (2006) moderating role of job position in the relationship between performance appraisal and affective commitment and intention stay. This show that employees at different position perceive differently to the performance appraisal which moderate the relationship between performance appraisal and outcome variables such as affective commitment, intention to stay and organizational citizenship behaviour.

\section{Conclusion and Suggestions}

This study shown that the performance appraisal practice which is one of the key HRM practices influence directly to the intention to stay and organizational citizenship behaver and indirectly through the affective commitment. Though the purpose of performance appraisal to evaluate the employee performance however, it influences employee attitude and behaviour. Therefore, organizations need to be careful while conducting performance appraisal. Organizations need to make sure that the performance appraisal process is fair and objective so that employee feel sense of justice. However, the perceived satisfaction with performance appraisal will positively affect employee attitude and behaviour. The performance appraisal satisfaction is most like to enhance affective commitment, intention to stay, and organizational citizenship behaviour.

The present study followed the literature review method and tested the propositions theoretically, in future empirical study would be conducted to prove the relationships statistically. The study could be conducted in the IT industry because IT companies implement performance appraisal system in their organization as a tool to evaluate employee performance. Empirical study will help the organizations to design and implement the performance appraisal practice is an effective way to curb issues such as lack of commitment, intention to leave and lack of positive volunteer behaviour.

\section{References}

[1] AbuAlRub, R. F., \& AL-ZARU, I. M. (2008). Job stress, recognition, job performance and intention to stay at work among Jordanian hospital nurses. Journal of nursing management, 16(3), 227-236.

[2] Ahuja, K. K., Padhy, P., \& Srivastava, G. (2018). Performance Appraisal Satisfaction \& Organizational Commitment. Indian Journal of Industrial Relations, 53(4).

[3] Allen, N. J., \& Meyer, J. P. (1990). The measurement and antecedents of affective, continuance and normative commitment to the organization. Journal of occupational psychology, 63(1), 1-18.

[4] Armstrong-Stassen, M., Freeman, M., Cameron, S., \& Rajacic, D. (2015). Nurse managers' role in older nurses' intention to stay. Journal of Health Organization and Management, 29(1), 55-74.

[5] Baron, R. M., \& Kenny, D. A. (1986). The moderator-mediator variable distinction in social psychological research: Conceptual, strategic, and statistical considerations. Journal of personality and social psychology, 51(6), 1173.

[6] Brown, M., Hyatt, D., \& Benson, J. (2010). Consequences of the performance appraisal experience. Personnel review, 39(3), 375-396.

[7] Charbonneau, D., \& Wood, V. M. (2018). Antecedents and outcomes of unit cohesion and affective commitment to the Army. Military Psychology, 30(1), 43-53.

[8] Chew, J., \& Chan, C. C. (2008). Human resource practices, organizational commitment and intention to stay. International journal of manpower, 29(6), 503-522.

[9] Devece, C., Palacios-Marqués, D., \& Alguacil, M. P. (2016). Organizational commitment and its effects on organizational citizenship behavior in a high-unemployment environment. Journal of Business Research, 69(5), 1857-1861.

[10] Dusterhoff, C., Cunningham, J. B., \& MacGregor, J. N. (2014). The effects of performance rating, leader-member exchange, perceived utility, and organizational justice on performance appraisal satisfaction: Applying a moral judgment perspective. Journal of business ethics, 119(2), 265-273.

[11] Harwiki, W. (2016). The impact of servant leadership on organization culture, organizational commitment, organizational citizenship behaviour (OCB) and employee performance in women cooperatives. Procedia-Social and Behavioral Sciences, 219, 283-290. 
[12] Heslin, P. A., \& VandeWalle, D. (2011). Performance appraisal procedural justice: The role of a manager's implicit person theory. Journal of Management, 37(6), 1694-1718.

[13] Iqbal, M. Z., Akbar, S., \& Budhwar, P. (2015). Effectiveness of performance appraisal: An integrated framework. International Journal of Management Reviews, 17(4), 510-533.

[14] Isenhour, L. C., Stone, D. L., Lien, D., Zheng, W., Zhang, M., \& Li, H. (2012). Performance appraisal process and organizational citizenship behavior. Journal of Managerial Psychology.

[15] Jang, J., \& Kandampully, J. (2018). Reducing employee turnover intention through servant leadership in the restaurant context: A mediation study of affective organizational commitment. International Journal of Hospitality \& Tourism Administration, 19(2), 125-141.

[16] Jaros, S. J. (1997). An assessment of Meyer and Allen's (1991) three-component model of organizational commitment and turnover intentions. Journal of vocational behavior, 51(3), 319-337.

[17] Juhdi, N., Pa'wan, F., \& Hansaram, R. M. K. (2013). HR practices and turnover intention: the mediating roles of organizational commitment and organizational engagement in a selected region in Malaysia. The International Journal of Human Resource Management, 24(15), 3002-3019.

[18] Jyoti, J., \& Rani, A. (2019). Role of burnout and mentoring between high performance work system and intention to leave: Moderated mediation model. Journal of Business Research, 98, 166-176.

[19] Kuvaas, B. (2006). Performance appraisal satisfaction and employee outcomes: mediating and moderating roles of work motivation. The International Journal of Human Resource Management, $17(3), 504-522$.

[20] Liu, W., Zhou, Z. E., \& Che, X. X. (2018). Effect of Workplace Incivility on OCB Through Burnout: the Moderating Role of Affective Commitment. Journal of Business and Psychology, 1-13.

[21] Lu, H., Yue, A., Han, Y., \& Chen, H. (2018). Exploring the Effect of Different Performance Appraisal Purposes on Miners' Organizational Citizenship Behavior: The Mediating Role of Organization Identification. Sustainability, 10(11), 4254.

[22] Meyer, J. P., \& Allen, N. J. (1991). A three-component conceptualization of organizational commitment. Human resource management review, 1(1), 61-89.

[23] Meyer, J. P., Stanley, D. J., Herscovitch, L., \& Topolnytsky, L. (2002). Affective, continuance, and normative commitment to the organization: A meta-analysis of antecedents, correlates, and consequences. Journal of vocational behavior, 61(1), 20-52.

[24] Min, M., Zhu, Y., \& Bambacas, M. (2019). The mediating effect of trust on the relationship between high-performance work systems and employee outcomes among Chinese indigenous firms. Asia Pacific Journal of Human Resources.

[25] Morrow, P. C. (2011). Managing organizational commitment: Insights from longitudinal research. Journal of vocational behavior, 79(1), 18-35.

[26] Organ, D. W. (1988). Organizational Citizenship Behaviour, Lexington, Lexington, MA.

[27] Palaiologos, A., Papazekos, P., \& Panayotopoulou, L. (2011). Organizational justice and employee satisfaction in performance appraisal. Journal of European Industrial Training, 35(8), 826-840.

[28] Phuong, T. H. (2018). Perceived justice in performance appraisal among Vietnamese employees: antecedents and consequences. International Journal of Business Excellence, 15(2), 209-221.

[29] Pradhan, S., \& Pradhan, R. K. (2015). An empirical investigation of relationship among transformational leadership, affective organizational commitment and contextual performance. Vision, 19(3), 227-235.

[30] Redditt, J., Gregory, A. M., \& Ro, H. (2019). An examination of organizational commitment and intention to stay in the timeshare industry: variations across generations in the workplace. International Journal of Hospitality \& Tourism Administration, 20(2), 206-225.

[31] Robinson, S. L., \& Morrison, E. W. (1995). Psychological contracts and OCB: The effect of unfulfilled obligations on civic virtue behaviour. Journal of organizational behaviour, 16(3), 289298.

[32] Saks, A. M. (2006). Antecedents and consequences of employee engagement. Journal of managerial psychology, 21(7), 600-619.

[33] Skarlicki, D. P., \& Folger, R. (1997). Retaliation in the workplace: The roles of distributive, procedural, and interactional justice. Journal of applied Psychology, 82(3), 434.

[34] Snape, E., \& Redman, T. (2010). HRM practices, organizational citizenship behaviour, and performance: A multi-level analysis. Journal of management studies, 47(7), 1219-1247. 
[35] Tang, T. W., \& Tang, Y. Y. (2012). Promoting service-oriented organizational citizenship behaviors in hotels: The role of high-performance human resource practices and organizational social climates. International Journal of Hospitality Management, 31(3), 885-895.

[36] Thurston Jr, P. W., \& McNall, L. (2010). Justice perceptions of performance appraisal practices. Journal of Managerial Psychology, 25(3), 201-228.

[37] Wang, Q., Weng, Q., \& Jiang, Y. (2018). When Does Affective Organizational Commitment Lead to Job Performance? Integration of Resource Perspective. Journal of Career Development, 0894845318807581.

[38] Zayas-Ortiz, M., Rosario, E., Marquez, E., \& Colón Gruñeiro, P. (2015). Relationship between organizational commitments and organizational citizenship behaviour in a sample of private banking employees. International Journal of Sociology and Social Policy, 35(1/2), 91-106.

[39] Zheng, W., Zhang, M., \& Li, H. (2012). Performance appraisal process and organizational citizenship behavior. Journal of Managerial Psychology, 27(7), 732-752. 